\title{
To see or be seen? The grounds of a place-based university
}

\section{Prophecy}

Spinoza, as the Dutch Ambassador to New Zealand, Rob Zaagman, reminded us in his welcome to the Arts of Spinoza + Pacific Spinoza, Interstices Under Construction Symposium held in Auckland in May 2017, radically undercut received wisdom, orthodox religion, and the political status quo. In the spirit of this radical Spinoza, we ask after the grounds of knowledge in the place now known as "the University of Auckland" (or Te Whare Wānanga o Tāmaki Makaurau). We take as our starting point the literal grounds of our University, which not only provided the site for the symposium's discussion about Spinoza and the Pacific, but which also establishes the parameters of what counts as knowledge through the grounding provided by its faculties, schools, and disciplines. We ask about the University's provenance, about the grounds it has secured for its functions-teaching, research, and service-and about the "built pedagogy" of its architecture and environs (Sturm \& Turner, 2011). To do so, we read into the University the history of its own construction, in order to get at the grounds of university-based knowledge more generally. ${ }^{1}$ The remit that Spinoza gives us to do so is partly supported by the University of Auckland's own aspiration to world excellence, which makes it a university just like any other aspiring world-excellent university, one which can stand in for the university in general, for the "idea of the university" today (Newman, 1996; Jaspers, 1959; Habermas, 1987). Indeed, the world-excellent university opens itself to the generic drive of all-inclusive or "transcendental capitalism" (de Cauter, 2002: 273). We argue that the optics of a Spinozan radical enlightenment enables us to ask after the grounds of knowledge, to ask what the university makes visible, and what, at the same time, is occluded by this visibility.

In "The Tyranny of Transparency", Marilyn Strathern argues that, in the university today, "visibility as a conduit for knowledge is elided with visibility as an instrument for control" (2000: 309). But the university is not simply a producer of knowledge, it is also an instrument of its control, one that establishes what can be known and how it comes to be known (Foucault, 1981: 94-95). The apparatus of the university, to borrow Gilles Deleuze's (1992) description of Foucault's dispositif (apparatus), is an "optical machine": it is "made of lines of light [...] distributing the visible and the invisible, giving rise to objects which are dependent 
Fig. 1 Sean Sturm (2017). Old Government House and lawn from the grove of oaks planted for the 1869 visit of Prince Alfred, Duke of Edinburgh [Photograph]. on it for their existence, and causing them to disappear" (160). In turn, this optical machine constructs "regimes of enunciation" (160), determining who can speak and what can be said within its panoptical ambit. This is to say that certain "lines of force [...] act as go-betweens between seeing and saying and vice versa, acting as arrows which continually cross between words and things, constantly waging war between them" (160). To adapt Deleuze and Félix Guattari's distinction from A Thousand Plateaus (1987), visibility thus becomes the "majoritarian" (given, normative) discourse, and invisibility the "minoritarian" (created, singular) discourse. Of course, who constitutes the "major" and the "minor" and how they speak in a settler-indigenous situation altogether depend on the time and place the question is posed and by whom. In the case of the University of Auckland, Deleuze's idiosyncratic reading of Spinoza's "optical geometry" (1997: 142) in "Spinoza and the three 'Ethics"” suggests to us a way to construct the settler imagination and its relation to a Māori place as a matter of movement. What moves in this place and, importantly, what moves us as denizens of this place are the more-than-human bodies that make up the "composite body" of the University of Auckland (Spinoza, 1992: 74; see Ruddick, 2017).

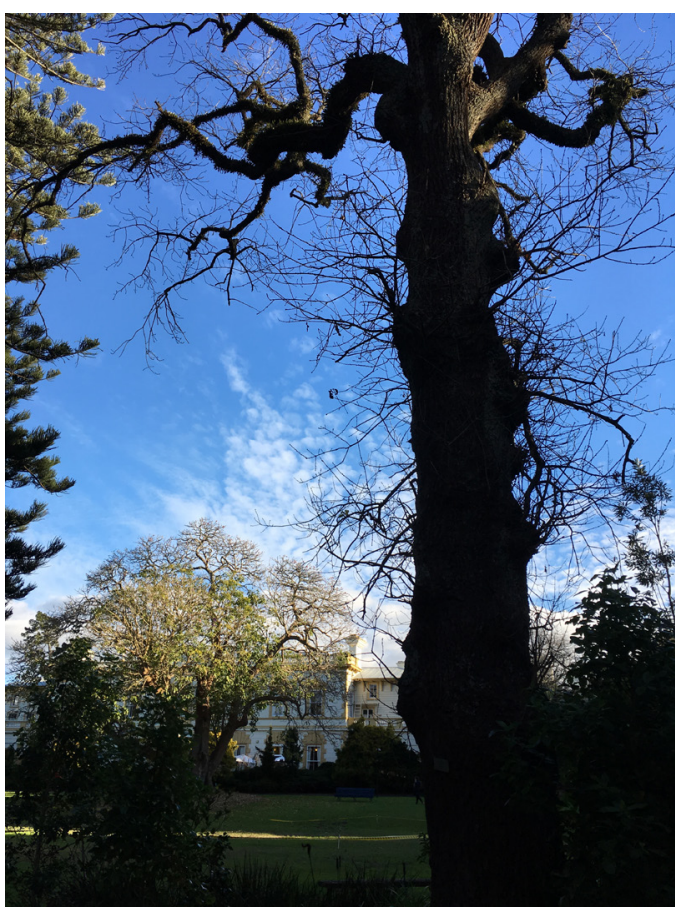

To ask after the grounds of the University is to respond to its more-than-humanand more-than-present-elements and to reconstruct, on that basis, a "common notion" (Spinoza, 1992: 89) of our inhabitation that constitutes its ground and the true grounds of knowledge. This enterprise, this "working on the ground" (Deleuze, 1992: 159), demands a certain prophetic procedure. We suggest, as a first step, actually walking the grounds of the university, touching its older standing structures, and thinking and talking about what it is that the newer ones have displaced. ${ }^{2}$ This process mirrors the Situationist dérive (drift), but is motivated less by "being drawn by the attractions of the terrain" (Debord, 2006: 8) than by opening up to the less-than-visible indigenous presence of the place. It might enable us to understand the operation of the tohu (signs) of the place by exploring their effects and affects (Deleuze, 1997) - their immediacy, or "firstness" (Peirce, 1974). ${ }^{3}$ 
Before we describe that prophetic procedure, we acknowledge another prophecy that marks the University as a Māori place-one signalled in the welcome to the Spinoza symposium by Michael Steedman from Ngāti Porou (one of the tāngata whenua, or peoples with customary authority, of the region). Rehearsing an ancestral tauparapara (incantation), he talked about the enduring need for spiritual connection to the land and a matakite (prophecy) by the seer Titai that foretold the coming of Europeans to Aotearoa/New Zealand and their landing at Tāmaki Makaurau/Auckland. The signs of their coming-namely, their sail as nautilus shell drifting in on the northerly wind and their flagstaff as carved post-constituted a prophecy that would in time transform the place of the tāngata whenua:

\author{
He aha te hau e wawara mai? \\ He tiu! He raki! \\ Nana i a mai te pupu tarakihi ki uta \\ E tikina atu e au te kotiu, \\ Koia te pou whakairo \\ Ka tu ki Waitemata \\ I aku wai te rangi e!
}

What is the breeze which gently hither blows?

It is a wind of the north-west and north

Which drifts hither the shell of the nautilus.

Were I to bring hitherward from the north-west

The ornamental post

To stand here in Waitemata

Fulfilled would be my vision, e! (Stone, 2001: 185-86)

But the bringing of Enlightenment, which was explicit in the mission of Captain Cook (Sahlins, 1995: 10-11) and implicit in the machinations of the Antipodean settlers who arrived in his wake, was at the same time a darkening of indigenous peoples' worlds. It created the now all-too-familiar racial chiaroscuro of light and shadow, good and bad, reason and unreason, scientific and superstitious knowledge.

However, it is possible-contra Spinoza's critique of prophecy in the TheologicalPolitical Treatise (2007) - to be drawn into the shadowlands of enlightened knowledge through a kind of prophecy by signs, a second sight that sees through the territorialising of place by the architectonics of cartography, cadastral and statistical survey, and systems of "accountability" that dominate the design and operation of social institutions like the university today (Carter, 1987; Hoskin, 1996; Shore \& Wright, 2000). Such an encounter with that fundament (Papatūānuku, or Earth Mother), as Carl Mika (2017) remarked at the symposium, is imbued with uncertainty. Indeed, the knowledge of prophecy is coloured by uncertainty, ignorance, and existential dread. Such knowledge is described by Spinoza (2007) in terms of the Hebrew word for spirit, ruagh, which means wind, variously conceived as life-breath, courage, capacity, sentiment, or indeed "the quarters of the world (because of the winds that blow from them), and also the sides of anything which look towards those quarters" (20-21). Taken in the context of Tāmaki Makaurau/Auckland, Spinoza's natura naturans (nature naturing; Spinoza, 1992: 52) could be read as the winds of change bringing colonising settlers to an indigenous place, or hau, the breath of life that Māori see as an enduring vitality that makes itself felt in the lands and waters of a place like 
the University of Auckland campus — but also through its absence in architecture like the University's Owen G. Glenn Business building (see Sturm \& Turner, 2011).

We propose a prophetic procedure that attends to the domain of the University of Auckland campus demarcated by the Albert Barracks wall. We ask why and how this structure exists, and what it tells us about "what happened here" and the grounds of local knowledge. We contend that the ongoing presence of the Barracks wall unsettles the grounds of university knowledge in this place, making of it a whenua tautohetohe (Mead, 1997), a contested territory. ${ }^{4}$ First, let us allow the historical archive to speak to how the campus came into being.

\section{Circumscription}

On 18 September 1840, 3000 acres on the Tämaki Isthmus, where the North Island (then "New Ulster") narrows to a few kilometres in width, was ceded or sold to Her Majesty's Government by Te Kawau (ariki tauaroa, or paramount chief ), his son Reweti, Tinana, and Horo (rangatira, or chiefs) of Ngāti Whätua-oŌrākei for an advance of six pounds-and some tobacco. ${ }^{5}$ The Governor, Captain William Hobson, had claimed "Autea" [Aotea] a week prior in a letter to his Chief Magistrate, William Symonds (F. \& S. Mathew, 1940:182-183). The signing of what the settlers took to be a provisional deed of sale was solemnised by toasts to the Queen, boat races and the raising of a flagstaff into which was cut the date and the name "Auckland" (Mathew 1940: 191)-named after the then Governor-General of India, Lord Auckland. On 20 October 1840, the parties signed the final Deed of Purchase for the isthmus (in total, Ngāti Whätua-o-Ōrākei received cash and goods worth £281, with a second payment of $£ 60$ in 1842). On 14 November 1840, having surveyed the isthmus, Surveyor-General Felton Mathew submitted his town plan for approval (F. \& S. Mathew, 1940: 196).

Fig. 2 Felton Mathew (1842). Plan of the town of Auckland, New Ulster, the capital of the colony of New Zealand [Map, Sir George Grey Special Collections, Auckland Libraries].

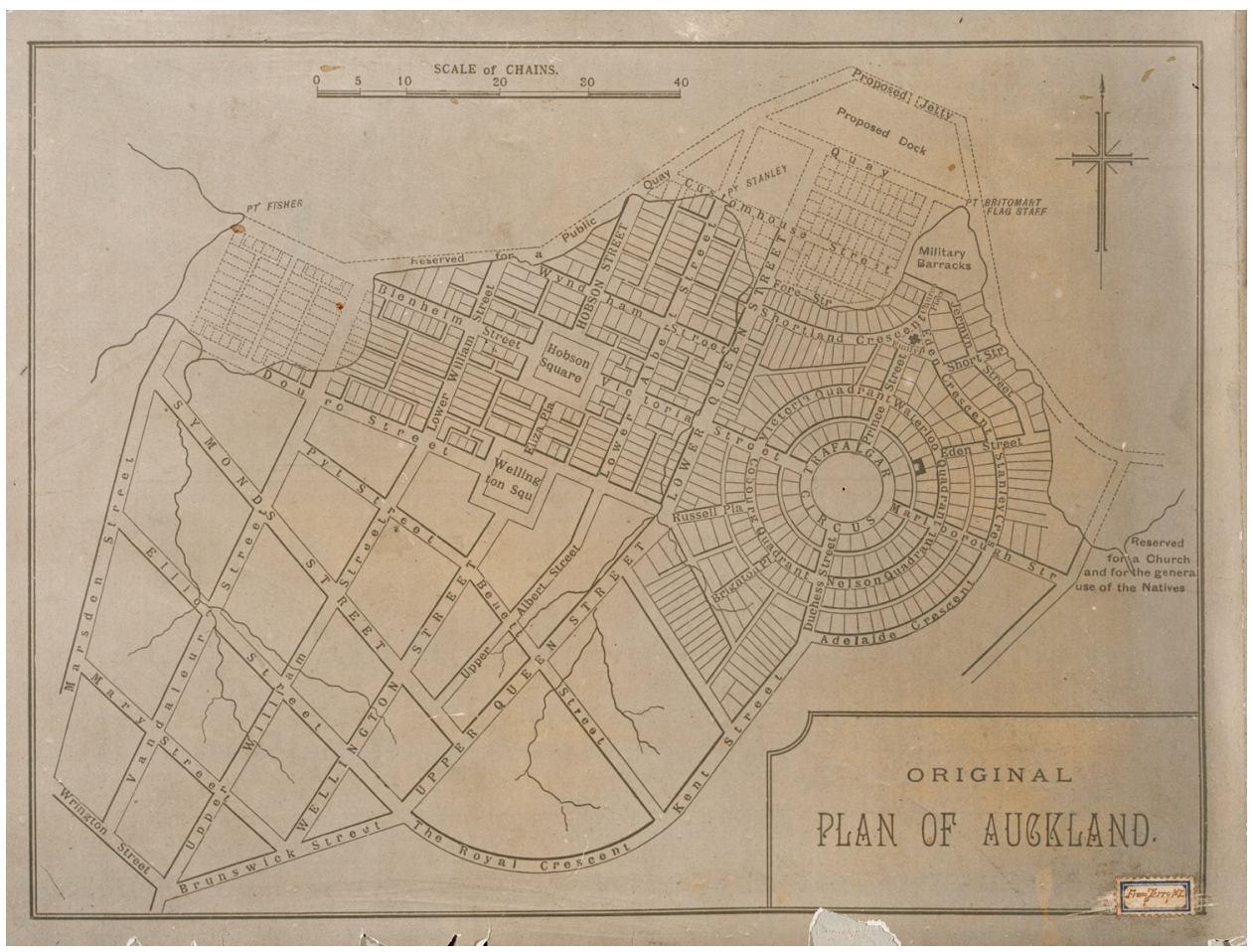


"Cobweb" Mathew planned the town of Auckland as a series of concentric circular streets radiating out from a circus on the elevated site of Albert Hill (Rangipuke), taking its cue from the circular volcanic plateau on which it sits and the volcanoes which define Auckland's landscape (Mathew, 1940: 197; see Brand, 2011). Although the plan (see Figure 2), probably based on that by John Nash for Regent's Park and Regent Street (Brand, 2011; Douglas, 2015; cf. Hamer, 1990), was approved by Governor William Hobson, it was never fully enacted, perhaps because of a shortage of surveyors or, indeed, a lack of political will to invest in such a grand design.

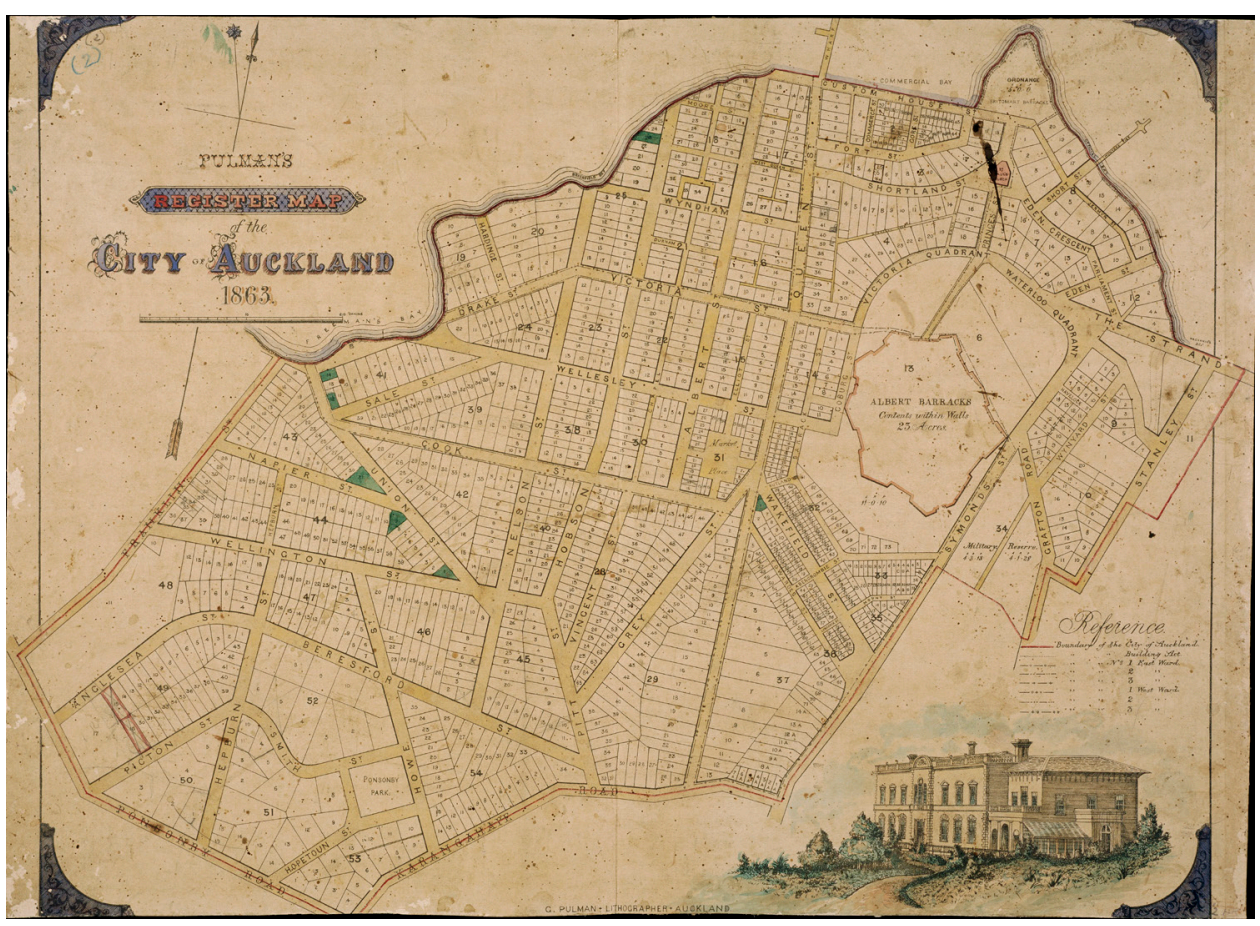

Fig. 3 George Pulman (1863) Pulman's register map of the city Special Collections, Auckland Libraries].

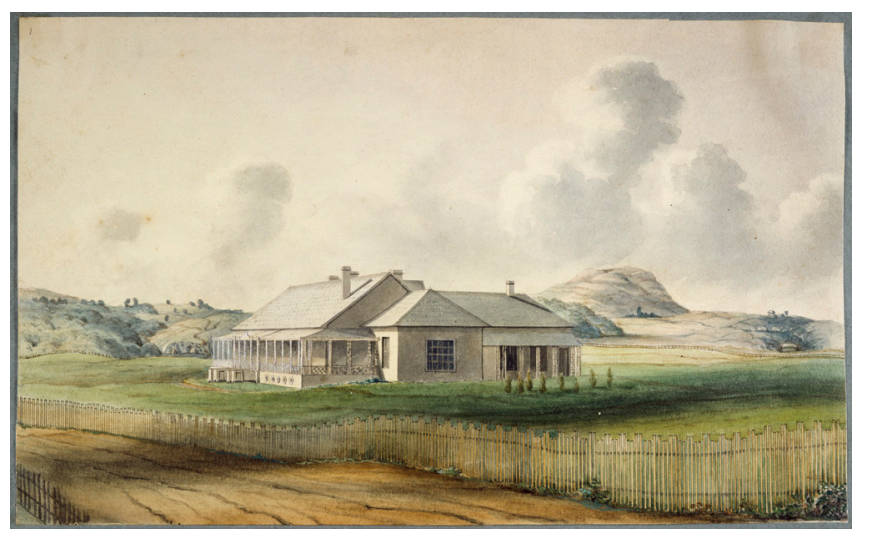

With the exception of two quadrants skirting one side of the field that became Albert Park and the precincts of Government House, Auckland was reduced to a grid that was creased by the gully that divided $i$, and down which flowed the "Queen Street River" (known then to Māori as Waihorotiu and later as the Ligar Canal) on the western border of what eventually became the main street of Auckland (see Figure 3 and Douglas, 2015). It ranged around a fortified barracks, rather than a circus, in an uncanny echo of the Pukerangi pa (village) that once occupied the site (Bulmer, 1994, citing Graham, 1980).

The first Government House at Auckland was a sixteen-room wooden structure prefabricated in London and modelled on that built in 1821 to house Napoleon on Saint Helena, Longwood House. It was imported in 1841 by Governor Hobson and erected on Waterloo Quadrant on a gently sloping tract of land to the northeast of the Albert Barracks. When it burned down in June 1848 during the governorship of George Gray, it was replaced with a larger Italianate house, again wooden but designed to look like stone (see inset in Figure 3, and Figure 4). Once the seat of 
Fig. 5 Unknown (c. 1860-1870s). Government House, Auckland [Photograph, Alexander Turnbull Library].
Government was relocated to Wellington in 1865, it became the northern residence for the Governor and official guests like Prince Alfred the Duke of Edinburgh and Queen Elizabeth II (McLean, 2006). In 1969, it was absorbed by the University of Auckland and became known as Old Government House. It now houses the Staff Club and is planned to become home to the Faculty of Law.

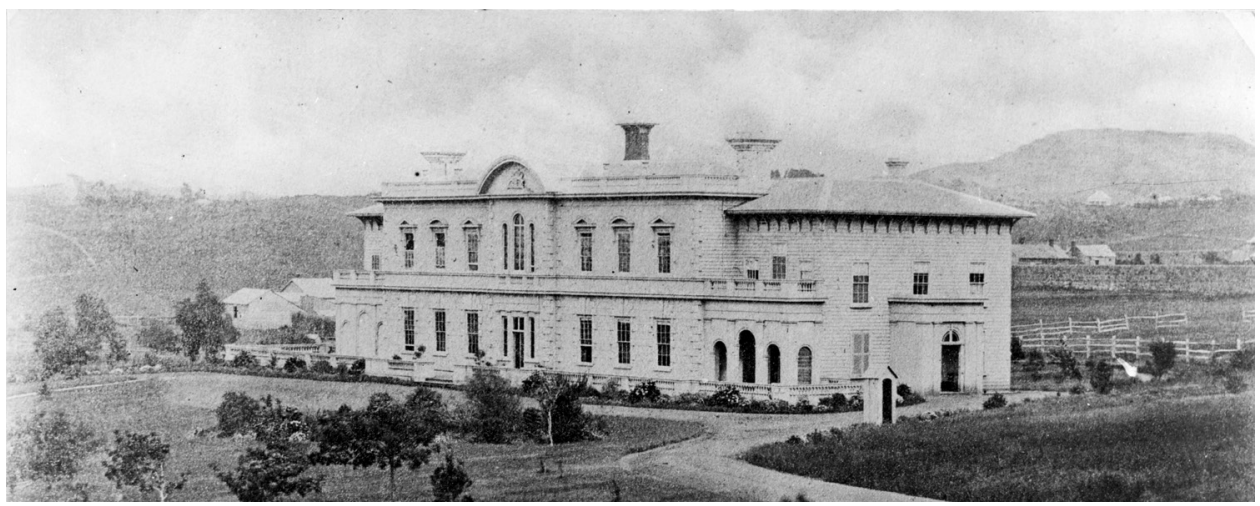

These extant documents make Albert Hill the centre of the new town of, capital for a time (1841-1865) of, the new Colony of New Zealand. Located on an existing elevated settlement (Rangipuke), the unsurveyed site is first overwritten by the Town Plan, then cleared for the Albert Barracks, then occupied by the first Government House and its levelled surrounds. A precinct-literally, "encirclement" in Latin-is as good a word as any for the bounded space of the would-be Government's House, behind which snakes the military barracks wall in a circle that would accommodate, enclose, and protect the small settler population from the tanngata whenua beyond. From the outset, then, the imagined threat of conflict underlay the settlers' governance of the territory, which would expand through land confiscation to the rest of Auckland, the North Island, and ultimately the whole country - the move of the University's Faculty of Law to this building that has been mooted in the University's building programme parallels these acts of circumscription upon which the law is founded. Beyond the cartography of town plans based on British models, the rationale of national law-before the 'nation' existed as such-required surveyors to establish the bounded plots of sections, suburbs, parks, farms, and roads. Governance thus hinged on the sovereign determination of property and its administration, which in turn founded the basis of law and suffrage in the new country. In this way, what Giselle Byrnes calls the "calligraphy of colonisation" (2001: 77) formalised the topography (literally, "land-writing") - via survey chains and theodolites-that enabled surveyors to measure and thereby create plots. The "ratio" of the chain (66 feet or 100 links in length, with an acre being 10 square chains) quite literally supplied the rationale for settlement and a law of circumscription.

Dr John Johnson, Colonial Surgeon, painted accounts of what David Filer (1999) has referred to as "life on the frontier" from the signing of the Treaty of the Waitangi onward. This watercolour sketch from the last year of his life shows a parade of the 58th (Rutlandshire) Regiment of Foot at the Albert Barracks before LieutenantGeneral Sir George Charles D'Aguilar, in the presence of a phlegmatic audience of tāngata whenua. The regiment was deployed in New Zealand from 1845-1859 and was commanded from 1851-1864 by General Edward Buckley Wynyard, who gave his name to the Auckland landmarks of Wynyard Wharf, Street, and, later, Quarter. 


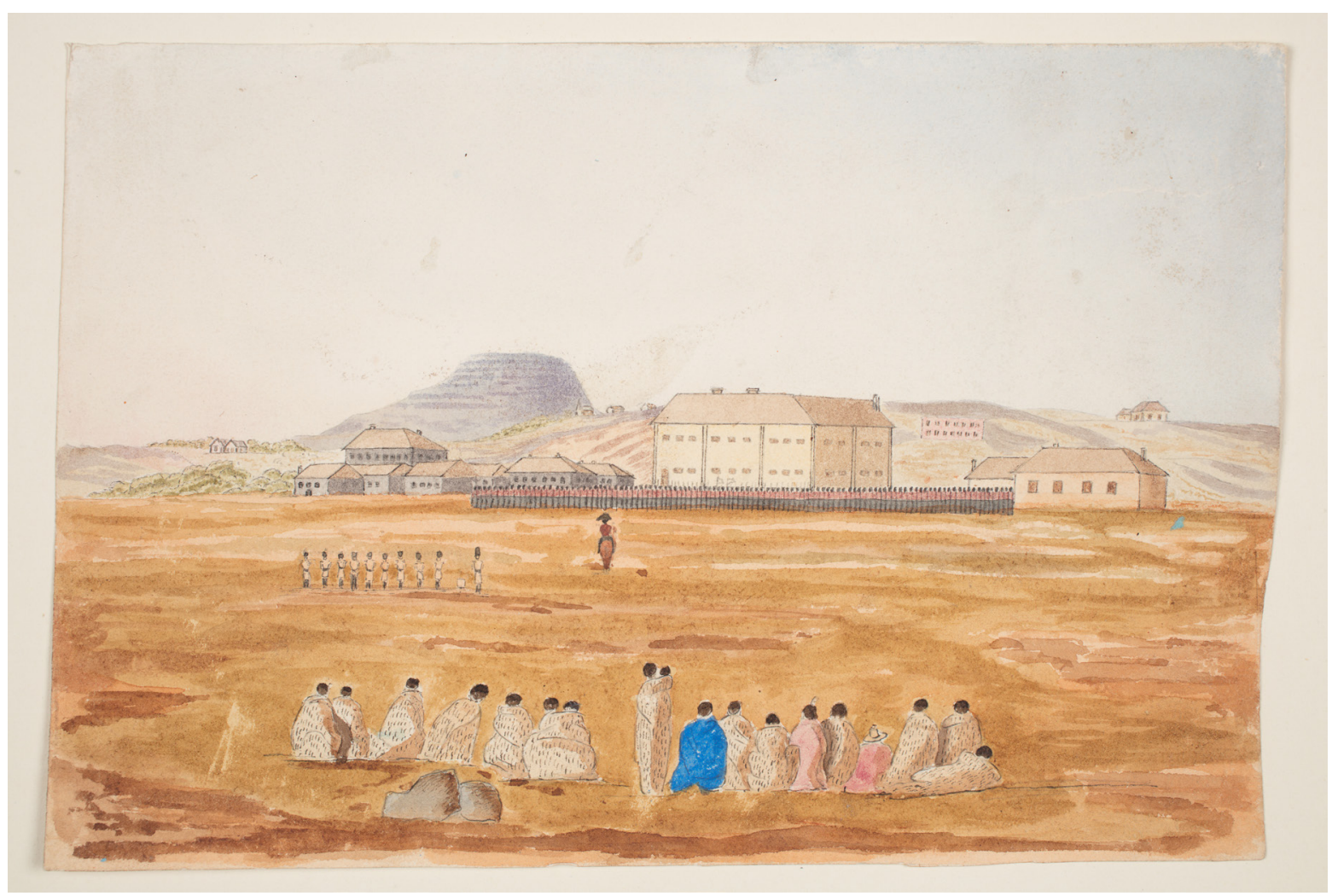

Fig. 6 John Johnson (1848). New barracks, Auckland, 1848 [Watercolour, Auckland War Memorial Museum].
No doubt, the rebuilt Government House, panopticon-like in its stately and forbidding survey of its surrounds, was read as a sign of the country-to-come. Its linearity, squareness, and stone construction appear at odds with the rolling landscape cleared for its establishment. Architecturally out-sized and out of place, as even settler critics of the Italianate design observed at the time (Sinclair \& McNaughton, 1983), its military activities, distinguished royal guests, and social and recreational events all worked to establish and secure a new mode of panoptical inhabitation. The building can be seen to have its eye on the local population, but, equally, the tāngata whenua have set their eyes on it and are fully attendant to the signifying work of settlement that it performs-hence the way in which the volcanic mound of Maungawhau/Mt Eden, once a pā of Te Wai-o-Hua (the iwi [tribe] defeated by Ngāti Whātua-o-Ōrākei in the mid-18th century), looms over it. Their lawful-or "lore"-ful (Barclay, 2005: 202) - gaze contests the grounding of the building, despite the 'legal' transaction that afforded settlers this foothold. Government House can be taken as a sign of things to come, as the property regime of encroaching settlement, and the agents and equipment of survey and militia that supported it, resulted in further contestation of land throughout the country (Belich, 2015) and spawned the defiant movements of Māori prophets_from Te Ua Haumēne (Pai Mārire/Hauhau), Te Whiti-o-Rongomai (at Parihaka), Te Kooti Arikirangi Te Turuki (Ringatū) to Rua Tapunui Kenana (at Maungapohatu) (Elsmore, 1989). The prophets were led by the existential dread occasioned by the settler spectacle to situate the spread of settlement in stories of regeneration of the peoples now calling themselves "Māori" (see Binney, 1999). In the context of signs that were read in both new and older terms of place-across the short settler history and the longer indigenous occupation-the law that Government House signifies and enacts quite literally a matter of where you stand, or sit ... with the past in front of you. 


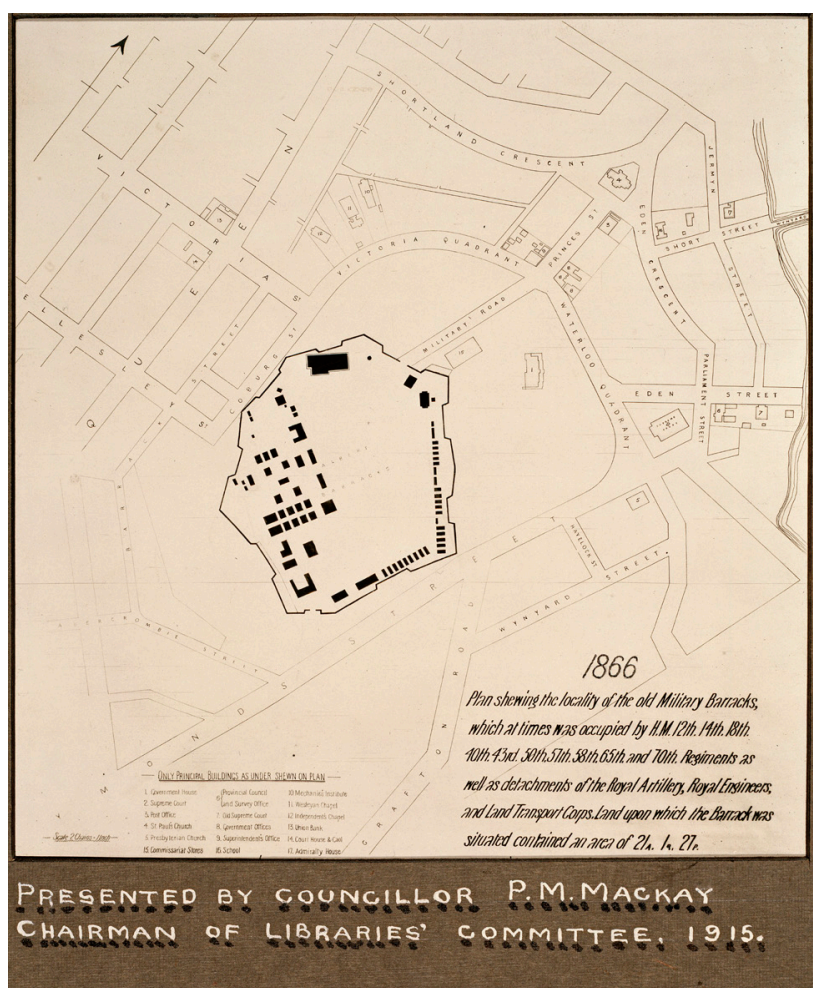

Fig. 7 Author unknown (1866).

Plan shewing the locality of the old Military Barracks [Map, Sir George Grey Special Collections, Auckland Libraries].
Fig. 8 J. D. Richardson (1860s). Inside Albert Barracks [Photograph, Sir George Grey Special Collections, Auckland Libraries].
The Albert Barracks was built between 1846 and 1852 to supplement Fort Britomart and to reassure the Auckland population after Hone Heke's 'rebellion' led to the Flagstaff War (1845-1846) in the Bay of Islands. It was soon to house more than 500 troops. George Graham of the Royal Engineers supervised the construction of a 1300-metre wall to enclose the 22 acres (8.9 ha) of the barracks and a number of buildings, including a magazine, a hospital, and a commissariat. Most were built by the more than 100 Māori stonemasons and builders from volcanic basalt blocks brought from the nearby Mt Eden Quarry (Sinclair \& McNaughton, 1983). Graham later claimed that the fortification of the barracks wasn't necessary but would prevent the subdivision of the hill and allow the area to become a park in a time of peace.

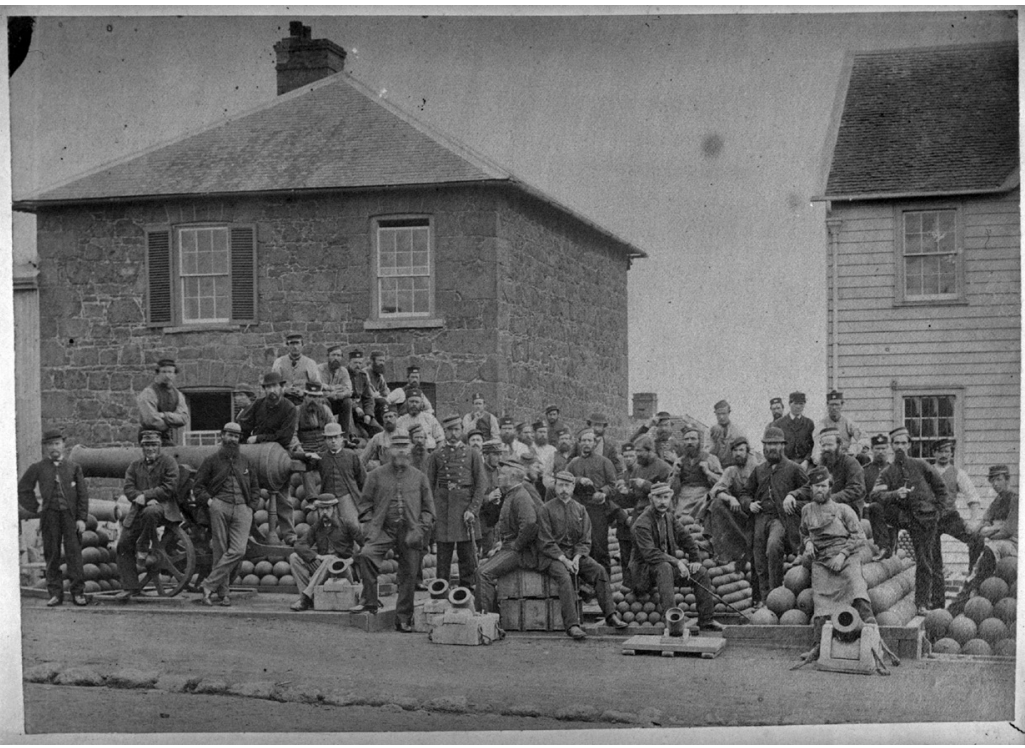

The Barracks was sent two Russian guns captured in the Crimea (see Figure 8): one is now at the Akarana Yacht Club in Auckland; the other, at the Waiouru Army Museum, while other military artefacts remain in Albert Park today. It was customary in the design of barracks from the 1830s to 1850s to centre on a parade ground for drills and punishments, but also leisure activities (Douet, 1998). To this end, in 1856 the parade ground was levelled and manicured by the military cricket club in preparation for cricket season (see Figure 9) (Clough, et al. 2003).

The Barracks was largely abandoned after the colonial capital was shifted to Wellington in 1865. The buildings and most of the wall were 


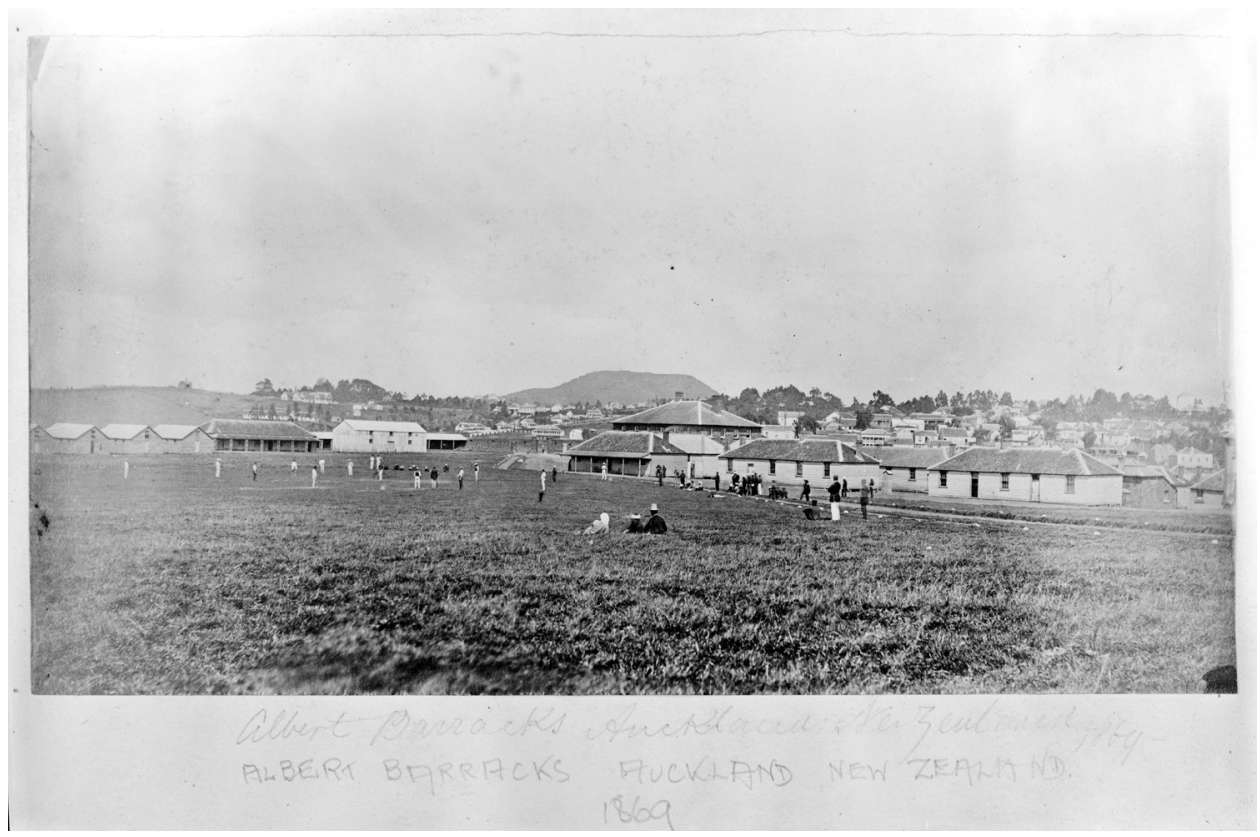

Fig. 9 Author unknown (1869). Cricket match at Albert Barracks, Auckland, 1869 [Photograph, Alexander Turnbull Library].

Fig. 10 Sean Sturm (2017). Barracks wall as seen from the University General Library side of the wall [Photograph]. demolished in 1870-1871 and the stone reused elsewhere, including in the construction of the local jail at Mt Eden (Coates, 1990; Clough, et al. 2003). 85 metres of the wall remain, dividing the old "100 Sector" of the University from the newer "300 Sector" and General Library.

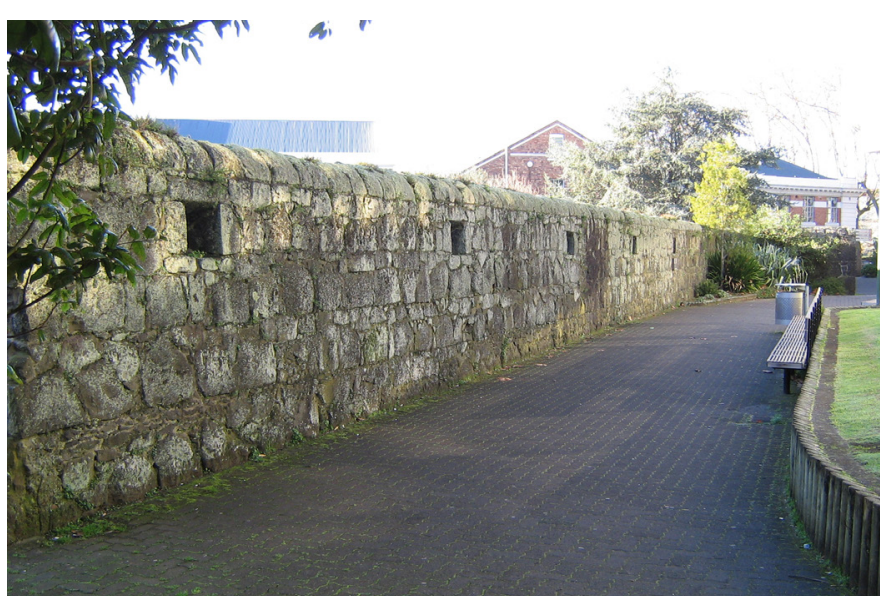

Walking the Barracks wall today (see Figure 10), we sense the complete circle it once formed. It is such acts of circumscription that establish settlers' claim to lawful presence. The instruments of survey and governance not only created a clearing, but also brought the sense of threat (threatening, but more importantly, being threatened) that gives the law its military foundation and produces, in sequence, a para-military, police, and prisons. Faced with questions of a constitutional nature, settlers (Pākehā [non-Māori New Zealanders] and migrants) today will tend to draw the same circle of fear and imagine a conflict that ultimately springs from their disavowal of other and older modes of inhabitation-and of Māori law/lore as "first law" (Mikaere, 2011: 14). In the case of the Government House precinct, given their fidelity to the settled site as is, it takes something akin to a leap of faith - a prophet-like act of imagination, indeed-for them to encounter the place beyond the flat circle of the Barracks wall's inscription. 


\section{Circumspection}

However, the panoptics of such circumscription obscures a shadow discourse, or scotoptics, that hides invisible "lines of flight", of "subjectivation" and "fracture" (Deleuze, 1992: 161). What moves and moves us in this place as we walk exceeds what is visible to the eye-although, thanks to John Johnson's painting (Figure 6), we can imagine that everything that takes and has taken place here is beheld, like the soldiers in the group portrait (Figure 9), by tāngata (peoples) and whenua (land). We can sense, as Carl Mika claimed in his probing of the mystery of ground (Papatūānuku) at the Spinoza symposium (2017), that even a tree may be "infused with the all". So may the trees dedicated to Prince Albert in the grounds of Government House (see Figure 1) be seen as bearing witness to the processes of settlement that led to the building of Government House and the installation of the colonial government. And thanks to Deleuze's (1997) reading of Spinoza's semiotics in the Ethics, we can see the signs of the place at work by exploring their effects and affects. We can read structures that express the place as "scalar" signs (scalar because they express the state of something at a moment in time). Scalar signs such as indices, icons, and symbols produce effects that are variously sensible ("indicative"), logical ("abstractive"), moral ("imperative"), or hermeneutic ("interpretive") (Deleuze, 1997: 138-140). Government House, for example, is altogether solid, upstanding, and progressive, a symbol of the early Colony and the University of New Zealand. But we can also read the structures as "vectorial" signs (vectorial because they express the change in something over time). Vectorial signs produce affects that are variously "augmentative", "diminutive", or "ambiguous", generating a play of light and dark (or joy and sadness, for Spinoza) that constitutes "degrees of chiaroscuro" (Deleuze, 1997: 140-141). The ClockTower, for example (see Figure 1), is a pou whakairo (ornamental post)

Fig. 11 Sean Sturm (2017). Michael Parekowhai's Kapa Haka (2008), from the Old Government House side of the Barracks wall [Photograph].

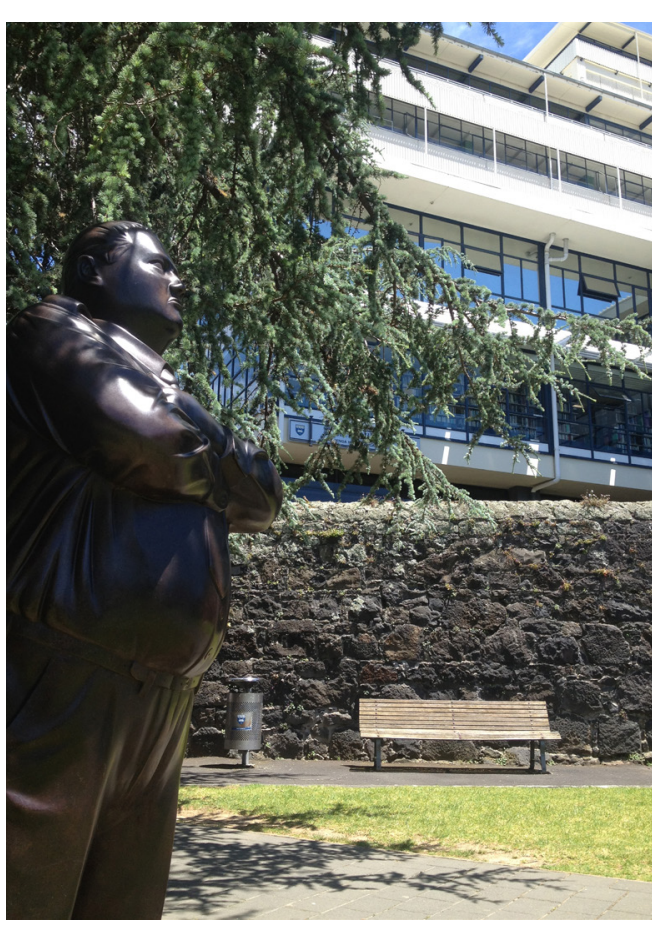
that drills into history and proliferates the affects of settlement, just as the raising of the flagstaff at Tāmaki must have done for Māori, for whom it was the fulfilment of the ambivalent prophecy of the coming of Pākehā. To be alert to such signs represents a kind of second sight-which is really a matter of seeing oneself or other things as other to the place, or better, of being seen by the place and its peoples as other. Seen this way, settlers and their history are "broken" (Turner, 2002): they are unsettled and their history is unfounded in the place. Nonetheless, their unsettlement signals the possibility of "lines of flight" (disappearances) that occasion "lines of fracture" or "subjectivation" such as ruptures in time and/or space or new forms of becoming (Deleuze, 1992: 161). ${ }^{6}$ To be moved by ground in a Māori place is thus to be beheld by tāngata and whenua.

When we walk the grounds of the campus in the shadow of the wall, we are called to circumspection. To come upon Michael Parekowhai's security guard in the ironic pose of the modern Māori warrior is to become aware of the Barracks wall and the University's General Library looming above it. ${ }^{7}$ The circumscription of the wall initialises the settler presence and secures the ground for the expansion of settler institutions and their archive. But the Library is not the only repository of knowledge in this place, nor the only means by which it is secured. And what the security guard-Māori, as is not untypical in New 
Zealand-might be securing remains obscure. The figure is a troubling transversal of the University's optics, an unsettling sign that might stand for the University as a site of knowledge and apparatus of control (and for its teachers as disciplinarians), or for Māori as both agents of settler securitisation and Māori circumspection. ${ }^{8}$ Altogether, it represents a composite body. For Spinoza (1992: 74,88 ), bodies moving or being moved in concert can resonate to form "composite bodies", of which "common notions" can be formed (as in when, for Deleuze [1997: 143], an "associative chain" becomes an "automatic chain"). The "human body" is one example of a composite body about which we form common notions; the "University of Auckland" is another-which implies that a body can be composed of human and more-than-human bodies (it's common knowledge today that the human body is composed of human elements allied with flora and often fauna). Susan Ruddick, in her keynote presentation at the symposium, went further. She took this capacity to be affected as indicative of ecological alliances at work between human and more-than-human bodies. Seen this way, the "composite body" of the University campus might be considered a "composition of forces" (Ruddick, 2017: 125), in other words, a body both tangible and intangible, human and others, that encompasses institution, archive, statue-and the ground on which they stand. A "common notion" of the University campus alert to its "degrees of chiaroscuro" (Deleuze, 1997: 141), to its lights and shadows, would thus have to encompass, extend, and even excavate its ground.

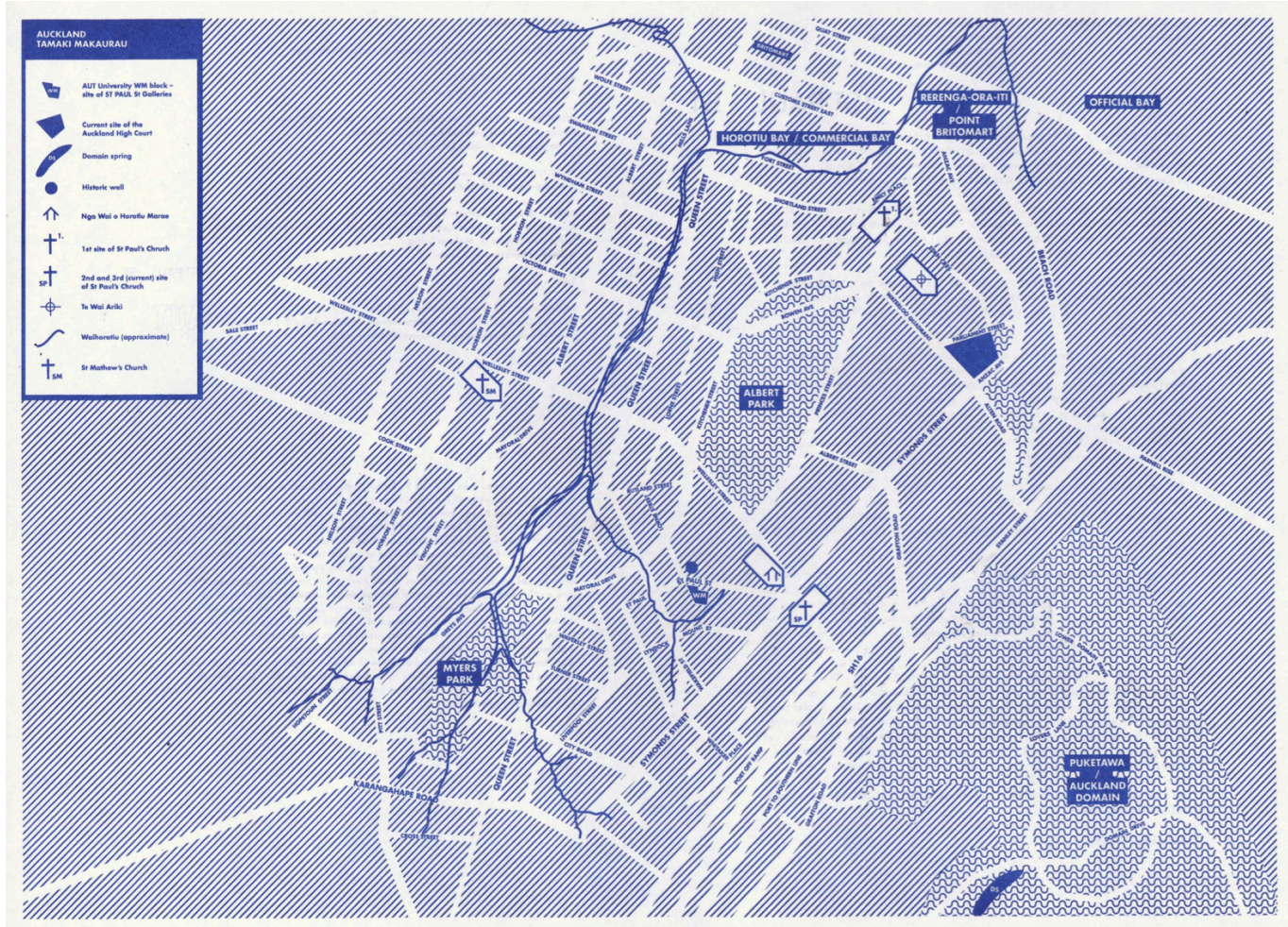

Fig. 12 Local Time (2014). Te Wai Ariki [Map]. Argos Aotearoa, 1, 5.
Three pā occupied Rangipuke at different times: Tangihanga Pukeā was situated on Rerenga-ora-iti (later Fort Britomart); Te Reuroa, near the present day High Court; and Pukerangi, in the north-western corner of Albert Park (Auckland City, 2009: 26). As the Local Time collective write,

All had ready access to the natural spring Te Wai Ariki (chiefly waters) located in what are now the grounds of the University of Auckland Faculty of Law. In 
the waterways from which Te Wai Ariki springs lived the taniwha [water spirit] Horotiu, after whom the stream that ran down present-day Queen Street and flowed into the bay Horotiu (later Commercial Bay) was named [...] its waters and taniwha now move under the streets of the CBD. (Local Time, 2014: 4)

The series of pā and the fort that underlie the University of Auckland campus might seem alike in their military function and their elevated survey of the surrounding lands, but the fort enacts circumscription, whereas the pā enact circumspection. The pā access the sacred subterranean spring, Te Wai Ariki, that is overseen by its taniwha, Horotiu (see Figure 12). Taniwha, as laid down by ancient tohunga (priests), are tohu (signs) and natural forces, guardians and dangers, that anchor and sustain a local community (Marsden, 2003: 19). Given the interdependence of pā residents and the spring, the taniwha calls for circumspection, an ethics of care towards its life-giving waters (the sewer canal later laid over its outlet in what is now Queen Street signifies a total ignorance of this knowledge [Douglas, 2015: 58]). All that happens in the place is beheld by, and beholden to, the taniwha, the agent and principle of uncertain ground, that looked on as the

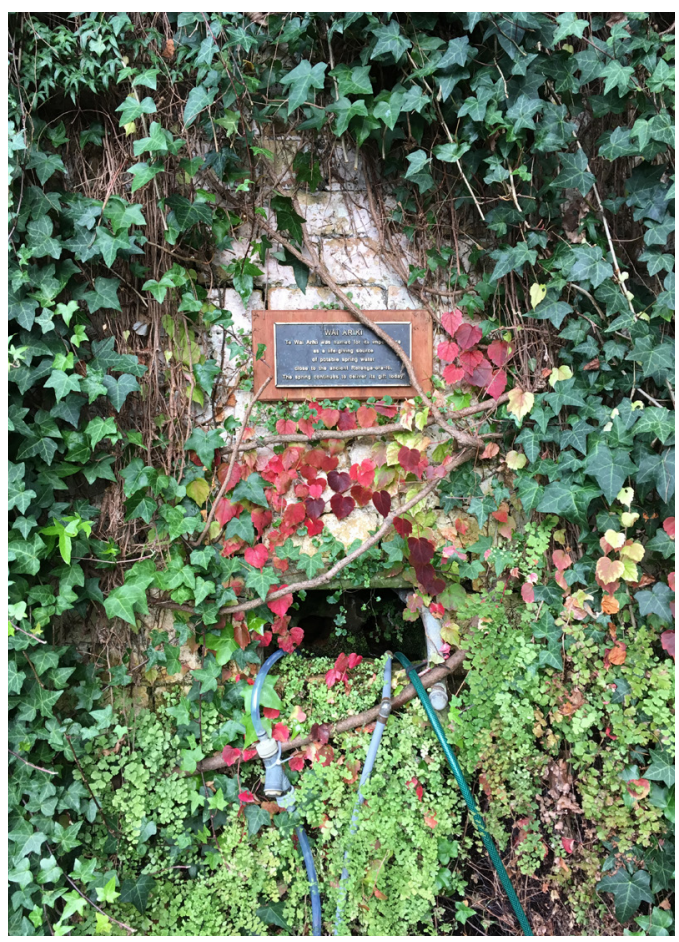
place was apparently transformed by the arrival of settlers, militia, government, and universities. Among other things, what this shadow discourse discloses is that the university occupies a transcendental-colonial-Māori place, a territory that is palimpsestic and contested, a whenua tautohetohe (Mead, 1997: 235). A common notion of this uncommon composition moves beyond the enlightened optics centred on the visible; it requires that the uncertainty of its less visible ground be attended to (as Philip Armstrong [2011] does when he hears the rumblings of Rūaumoko in the earthquake-torn landscape of Christchurch). To do so might enable settlers to seek a solidarity grounded in their relative ignorance and to approach the grounds of (this) place with an uncertainty that would enable the real encounters and alliances otherwise foreclosed by their self-circumscription. Such encounters and alliances might also reveal that the university too is more than it seems, which it must be if it is to be a "pluriversity" (cf. De Sousa Santos, 2009): a place of possibilities, upbuilding, and practical wisdom; a wānanga (place of learning) and not just another placeless neoliberal university that produces nothing but certain and circumscribed knowledge.

Fig. 13 Sean Sturm (2017). Te Wai Ariki spring outlet, University of Auckland Faculty of Law carpark [Photograph].
Thus, one way in which we as scholars can ask after the ground rules of our university-or perhaps of any university in an indigenous place-is to ask after the ground on which it sits. Ours is sited on a former colonial fort, Albert Barracks, and on the site of a number of former indigenous pā. The Barracks wall conspicuously bisects the campus; the Te Wai Ariki stream that sustained the pã issues inconspicuously via a tap in the carpark of the Faculty of Law (see Figure 13). But seeing the university, as it were, in view of the place in which it sits and of everything that has happened there means more than reading the place as a historical palimpsest; it means seeing the correspondences between its military history and the paramilitary nature of management in the "university of excellence" (Readings, 1996: 11; see Hoskin, Macve, \& Stone, 2006), and between its enterprise and that of militant colonialism and neo-colonialism (Chatterjee \& Maira, 2014). Moreover, it is to see it as an "uncommon commons" (Turner, 
2013: 26), an eruption of place in the generic "non-place" (Augé, 1995) of the transcendental "university of excellence" (Readings, 1996: 11). And that uncommon commons might even presage an Oceanic "undercommons", to borrow a term from Harney \& Moten (2013; see Hau'ofa, 1993), shared by indigenous peoples across the Pacific, but not necessarily by non-indigenous peoples-though they might otherwise "share" the same place. Such is the hope that an ethic of care toward the place and its peoples holds out-a fidelity to what moves and to being moved-such that we scholars tautoko (affirm) the whakatauki "toitū te whenua; toitū te tangata" (as the land endures, so do the people). 
Brand, D. (2011). Crossing the roads: Urban diagonals in New Zealand and the nineteenth century Anglo-colonial world. Planning Perspectives, 26(3), 423-444.

Bulmer, S. (1994). Sources for the archaeology of the Mãori settlement of the Tāmaki volcanic district. Wellington, New Zealand: Department of Conservation.

Byrnes, G. (2001). Boundary markers: Land surveying and the colonisation of New Zealand. Palmerston North, New Zealand: Bridget Williams

Carter, P. (1987). The road to Botany Bay: An essay in spatial history. London, UK: Faber \& Faber.

\section{REFERENCES}

Armstrong, P. (2011). On tenuous grounds. Landfall, 222, 8-19.

Ashworth, E. (1842/1843). Government House, Auckland: NW view. Alexander Turnbull Library, Wellington, New Zealand. Ref:E-216-f-005. Retrieved from https://natlib.govt.nz/ records/23035127

Auckland City. (2009). The learning quarter plan. Auckland, New Zealand: Auckland Council. Retrieved from https://cdn. auckland.ac.nz/assets/auckland/ about-us/the-university/ affliations-and-associations/ learning-quarter.pdf

Augé, M. (1995). Non-places: Introduction to an anthropology of supermodernity (J. Howe, Trans.). New York, NY: Verso.

Barclay, B. (2005). Mana tūturu: Maori treasures and intellectual property rights. Auckland, New Zealand: Auckland University Press.

Belich, J. (2015). The New Zealand wars and the Victorian interpretation of racial conflict. Auckland, New Zealand: Auckland University Press.

Binney, J. (1999). Songlines from Aotearoa. In K. Neumann, N. Thomas, \& H. Ericksen (Eds.), Quicksands: Foundational histories in Australia \& Aotearoa New Zealand (pp. 218-267). Sydney, Australia: New South Wales University Press. (2014). The imperial university: Race, war, and the nation-state. In P. Chatterjee \& S. Maira (Eds.), The imperial university: Academic repression and scholarly dissent (pp. 1-50). Minneapolis, MN: University of Minnesota Press.

Clough, R., Bader, H. D., Mace, T., Fraser, J., Rudd, D., Hawkins, S., Low, J., Sutherland, C., Macready, S., \& Wallace, R. (2003).

Excavation of the Albert Barracks (R11/833): University of Auckland student amenities project (Unpublished Client Report). Auckland, New Zealand: Clough \& Associates for the University of Auckland. Retrieved from http:// www.clough.co.nz/monographs/ clough_albert_barracks.pdf

Coates, J. M. (1990). Bluestone and bureaucracy: A project on the presentation of an archaeological site, Albert Barracks R11/833 (Unpublished Internal Report). Wellington, New Zealand: Regional Archaeology Unit for Science and Research Division, Department of Conservation. Retrieved from http://www.doc. govt.nz/documents/science-andtechnical/srir65.pdf

Cricket match at Albert Barracks, Auckland, 1869 (1869). Reference Number: PA1-f-027-19-1. Wellington, New Zealand: Alexander Turnbull Library. Retrieved from http://mp.natlib. govt.nz/detail/?id=36337\&l=en

Debord, G. (2006). Theory of the dérive. In K. Knabb (Ed.), Situationist international anthology (K. Knabb, Trans.) (pp. de Cauter, L. (2002). The capsular civilization. In N. Leach (Ed.), The hieroglyphics of space: Reading and experiencing the modern metropolis (pp. 271-280). London, UK: Routledge.

Deleuze, G. (1986). Cinema 1: The movement-image $(\mathrm{H}$. Tomlinson \& B. Habberjam, Trans.). Minneapolis, MN: University of Minnesota Press.

Deleuze, G. (1992). What is a dispositif? In T. Armstrong (Ed.), Michel Foucault, philosopher: Essays (pp. 159-168). New York, NY: Routledge.

Deleuze, G. (1997). Spinoza and the three "Ethics". In G. Deleuze, Essays critical and clinical (D.W. Smith \& M.A. Greco, Trans.) (pp. 138-151). Minneapolis, MN: University of Minnesota Press. 8-12). Berkeley, CA: Bureau of Public Secrets.
Deleuze, G., \& Guattari, F. (1986).

Kafka: Toward a minor literature (D. Polan, Trans.). Minneapolis, MN: University of Minnesota Press.

Deleuze, G., \& Guattari, F. (1987). A thousand plateaus: Capitalism and schizophrenia, vol. 2 (B. Massumi, Trans.). Minneapolis, MN: University of Minnesota Press.

Derrida, J. (1983). The principle of reason: The university in the eyes of its pupils. diacritics, 13(3), 3-20.

De Sousa Santos, B. (2009). The university in the twenty-first century: Towards a democratic and emancipatory university reform. In M. W. Apple, S. J. Ball, \& L. A. Gandin (Eds.), The Routledge international handbook of the sociology of education (pp. 274-282). London, UK: Routledge.

Douet, J., \& Saunders, A. (1998). British barracks 1600-1914: Their architecture and role in society. Norwich, UK: Her Majesty's Stationery Office.

Douglas, A. (2015). Plan/ditch: Topographic inscription in an early colonial capital. Interstices: Journal of Architecture and Related Arts, 16, 57-71.

Elsmore, B. (1989). Mana from heaven: A century of Māori prophets in New Zealand. Tauranga, New Zealand: Moana Press.

Filer, D. (1999). Painting the frontier: The art of New Zealand's pioneers. Auckland, New Zealand David Bateman
Foucault, M. (1981). The history of sexuality: An introduction (R. Hurley, Trans.). Harmondsworth, UK: Penguin.

Government House, Auckland. (c. 1860s-1870s). Alexander Turnbull Library, Wellington, New Zealand. Reference number: 1/2-105456-F. Retrieved from http://mp.natlib. govt.nz/detail/?id=15444\&l=en

Graham, G., \& Simmons, D. R. (Ed.). (1980). Maori place names of Auckland: Their meaning and history. Auckland, New Zealand: Auckland Institute and Museum.

Habermas, J. (1987). The idea of the university: Learning processes. New German Critique, 41,3-22.

Hamer, D. (1990). New towns in the New World: Images and perceptions of the nineteenthcentury urban frontier. New York, NY: Columbia University Press.

Hamilton, S. (2011, August 4). Stepping down the Great South Road. Reading the maps. Retrieved from http:// readingthemaps.blogspot. co.nz/2011/08/stepping-downgreat-south-road.html

Harney, S., \& Moten, F. (2013). The undercommons: Fugitive planning and black study. New York, NY: Minor Compositions.

Hau'ofa, E. (1993). A new Oceania: Rediscovering our sea of islands. Suva, Fiji: The University of the South Pacific.

Hoskin, K. (1996). The "awful idea of accountability": Inscribing people into the measurement of objects. In R. Munro \& J. Mouritsen (Eds.), Accountability: Power, ethos and the technologies of managing (pp. 265-282). London, UK: International Thomson Business Press.

Hoskin, K., Macve, R., \& Stone, J. (2006). Accounting and strategy: Towards understanding the historical genesis of modern business and military strategy. In A. Bhimani (Ed.), Contemporary issues in management accounting (pp. 166-197). Oxford, UK: Oxford University Press.

Jaspers, K., \& Deutsch, K. W. (Ed.). (1959). The idea of the university (H. A. T. Reiche \& H. F. Vanderschmidt, Trans.). Boston, MA: Beacon Press. 
Johnson, J. (1848). [New barracks, Auckland, 1848.] Auckland War Memorial Museum, Auckland, New Zealand. Reference number: PD-1963-8-10. Retrieved from http://www.aucklandmuseum. com/collection/object/am_ library-paintinganddrawings-535

Local Time. (2014). Te wai ariki. Argos Aotearoa, 1, 4-5.

Marsden, M. (2003). The woven universe: Selected writings of Rev Māori Marsden (T. C. Royal, Ed.). Otaki, New Zealand: Estate of Rev. Māori Marsden.

Mathew, F. (1842). Plan of the town of Auckland, New Ulster, the capital of the colony of New Zealand. Sir George Grey Special Collections, Auckland Libraries, Auckland, New Zealand. Reference number: NZ Map 4611. Retrieved from http://www. aucklandcity.govt.nz/dbtw-wpd/ Heritagelmages/images/maps/ maps110f/4611.jpg

Mathew, F., Mathew S., \& Rutherford, J. (Ed.). (1940). The founding of New Zealand: The journals of Felton Mathew, first surveyor-general of New Zealand and his wife, 1840-1847. Auckland, New Zealand: A.H. \& A.W. Reed.

McLean, G. (2006). The governors: New Zealand's governors and governorsgeneral. Dunedin, New Zealand: University of Otago Press.

Mead, L. T. T. R. (1996). Ngā aho o te kakahu matauranga: The multiple layers of struggle by Māori in education [Unpublished thesis for the Doctor of Philosophy]. University of Auckland, New Zealand.

Mead, S. M. (1997). Landmarks, bridges and visions: Aspects of Māori culture: Essays. Wellington, New Zealand: Victoria University Press.

Michels, C., \& Beyes, T. (2014). Performing university space: Multiplicity, relationality, affect. In P. Temple (Ed.), The physical university: Space and place in higher education (pp. 15-33). Abingdon, UK: Routledge.

Mika, C. (2017). Pacific Spinoza/ Pacific spaces. Presentation at the Interstices Under Construction Symposium: The Arts of Spinoza + Pacific Spinoza. Auckland, New Zealand, 26-28 May 2017.
Mikaere, A. (2011). Colonising myths/Maori realities: He rukuruku whakaaro. Wellington, New Zealand: Huia \& Te Tākupu, Te Wānanga-o-Raukawa.

Newman, J. H., \& Turner, F. M. (Ed.). (1996). The idea of a university. New Haven, CT: Yale University Press.

Pierce, C. S. (1974). Collected papers of Charles Sanders Peirce (Vol. 5, C. Hartshorne \& P. Weis, Eds.). Cambridge, MA: Belknap Press.

Plan showing the locality of the old Military Barracks, which at times was occupied by H.M. 12th, 14th, 18th, 40th, 43rd, 50th, 58th, 65th, and 70th, regiments as well as detachments of the Royal Artillery, Royal Engineers and Land Transport Corps. (1866). Reference number: NZ Map 4616. Auckland, New Zealand: Sir George Grey Special Collections, Auckland Libraries. Retrieved from http://www. aucklandcity.govt.nz/dbtw-wpd/ Heritagelmages/images/maps/ maps157f/4621.jpg

Pulman, G. (1863). Pulman's register map of the city of Auckland. Reference number: NZ Map 4475-1. Auckland, New Zealand: Sir George Grey Special Collections, Auckland Libraries.

Readings, B. (1996). The university in ruins. Cambridge, MA: Harvard University Press.

Richardson, J. D. (1860s). Inside Albert Barracks. Reference number: 4-423. Auckland, New Zealand: Sir George Grey Special Collections, Auckland Libraries, Retrieved from http://www. aucklandcity.govt.nz/dbtw-wpd/ Heritagelmages/images/photos/ p2Of/img0057.jpg

Richardson, T. (2014). A schizocartography of the University of Leeds: Cognitively mapping the campus. disClosure: A Journal of Social Theory, 23(1), 131-153. Retrieved from http:// uknowledge.uky.edu/disclosure/ vol23/iss $1 / 10$

Ruddick, S. (2017). Rethinking the subject, reimagining worlds. Dialogues in Human Geography, 7(2), 119-139.

Sahlins, M. (1995). How "natives" think: About Captain Cook, for example. Chicago, IL: University of Chicago Press.
Shore, C., \& Wright, S. (2000). Coercive accountability: The rise of audit culture in higher education. In M. Strathern (Ed.), Audit cultures: Anthropological studies in accountability, ethics and the academy (pp. 57-89). London, UK: Routledge.

Sinclair, K., \& McNaughton, T. (1983). A history of the University of Auckland, 1883-1983.

Auckland, New Zealand: Auckland University Press.

Spinoza, B., \& Feldman, S. (Ed.). (1992). Ethics, with the treatise on the emendation of the intellect and selected letters (S. Shirley, Trans.). Indianapolis, IN: Hackett.

Spinoza, B. \& Israel, J. (Ed.). (2007). Theological-political treatise (M. Silverthorne \& J. Israel, Trans.). Cambridge, UK: Cambridge University Press.

Stone, R. C. J. (2001). From Tāmaki-Makau-Rau to Auckland: A history of Auckland. Auckland, New Zealand: Auckland University Press.

Strathern, M. (2000). The tyranny of transparency. British Educational Research Journal, 26(3), 309-321.

Sturm, S., \& Turner, S. (2011). "Built pedagogy": The University of Auckland Business School as Crystal Palace. Interstices: Journal of Architecture and Related Arts, 12, 23-34.

Sturm, S., \& Turner, S. (2013). The university beside itself. In T. Besley and M.A. Peters (Eds.), Reimagining the creative university (pp. 49-59). Rotterdam,

Netherlands: Sense.

Turner, S. (2002). Being colonial/ colonial being. Journal of New Zealand Literature (JNZL), 20, 39-66.

Turner, S. (2013).

Anglosphericism. Journal of New Zealand Literature (JNZL), 31(2), 15-34.

Waitangi Tribunal. (1987). Report of the Waitangi Tribunal on the Orakei claim (Wai 9). Wellington, New Zealand: Waitangi Tribunal, Department of Justice.

\section{ENDNOTES}

1 For Jacques Derrida's reading of the university in terms of the physical grounds of Cornell University, see "The Principle of Reason: The University in the Eyes of its Pupils" (Derrida, 1983).

2 For other examples of psychogeographical critical university studies, see Beyes \& Michels (2014) and Richardson (2014).

3 Compare Deleuze (1986: 98-99) on firstness.

4 According to Mead, the concept of whenua tautohetohe, or "debateable lands" on the shared boundary between the lands of iwi (tribes), "allows for dynamic political and social relations between neighbouring tribes and reflects the ebb and flow of iwi politics" (1997: 236), unlike the fixed boundary of surveyed lands.

5 The deed comprised a wedge of land running along the Waitematā foreshore from Hobson Bay to the Whau creek and inland to Maungawhau (Mt Eden). For the vexed status of the Deed of Sale of the Tàmaki isthmus, see Stone (2001: 261-262) and Waitangi Tribunal (1987).

6 Deleuze and Guattari's term lignes de fuite is often translated "lines of flight", but strictly speaking it denotes the lines that converge on a vanishing point in linear perspective. Fuite literally means "escape", "leak" or "disappearing into the distance" (Deleuze \& Guattari 1987: xvi).

7 The title of Parekowhai's sculpture, Kapa Haka (literally, "line-dance"), draws an ironic link between the ritualised gestures of Māori performing arts and a common pose of security guards in New Zealand, many of whom are of Māori descent.

$8 \mathrm{It}$ is a little-known fact that the University of Auckland was the recipient of endowments of land confiscated from several North Island iwi, in particular, Ngāti Awa and Tainui, as Linda Mead (later Linda Tuhiwai-Smith) documents in her PhD thesis Nga aho o te kakahu matauranga (Mead, 1996: 96, citing Sinclair \& McNaughton, 1983: 30). 